\title{
Debris flood hazard documentation and mitigation on the Tilcara alluvial fan (Quebrada de Humahuaca, Jujuy province, North-West Argentina)
}

\author{
G. Marcato $^{1}$, G. Bossi ${ }^{1}$, F. Rivelli ${ }^{2}$, and L. Borgatti ${ }^{3}$ \\ ${ }^{1}$ CNR-IRPI - National Research Council of Italy, Research Institute for Hydrological and Geological Hazard Prevention, \\ C.so Stati Uniti 4, 35127 Padova, Italy \\ ${ }^{2}$ Departamento de Ciencias Naturales, Universidad Nacional de Salta, Casilla De Correo 529, 4400 Salta, Argentina \\ ${ }^{3}$ Department of Civil, Environmental and Materials Engineering DICAM, Alma Mater Studiorium Università di Bologna, \\ Viale Risorgimento 2, 41136 Bologna, Italy
}

Correspondence to: G. Marcato (gianluca.marcato@irpi.cnr.it)

Received: 22 December 2011 - Revised: 26 March 2012 - Accepted: 28 March 2012 - Published: 13 June 2012

\begin{abstract}
For some decades, mass wasting processes such as landslides and debris floods have been threatening villages and transportation routes in the Rio Grande Valley, named Quebrada de Humauhuaca. One of the most significant examples is the urban area of Tilcara, built on a large alluvial fan. In recent years, debris flood phenomena have been triggered in the tributary valley of the Huasamayo Stream and reached the alluvial fan on a decadal basis.
\end{abstract}

In view of proper development of the area, hazard and risk assessment together with risk mitigation strategies are of paramount importance. The need is urgent also because the Quebrada de Humahuaca was recently included in the UNESCO World Cultural Heritage. Therefore, the growing tourism industry may lead to uncontrolled exploitation and urbanization of the valley, with a consequent increase of the vulnerability of the elements exposed to risk. In this context, structural and non structural mitigation measures not only have to be based on the understanding of natural processes, but also have to consider environmental and sociological factors that could hinder the effectiveness of the countermeasure works.

The hydrogeological processes are described with reference to present-day hazard and risk conditions. Considering the socio-economic context, some possible interventions are outlined, which encompass budget constraints and local practices. One viable solution would be to build a protecting dam upstream of the fan apex and an artificial channel, in order to divert the floodwaters in a gully that would then con- vey water and sediments into the Rio Grande, some kilometers downstream of Tilcara. The proposed remedial measures should employ easily available and relatively cheap technologies and local workers, incorporating low environmental and visual impacts issues, in order to ensure both the future conservation of the site and its safe exploitation for inhabitants and tourists.

\section{Introduction}

In the area of Tilcara village $\left(23^{\circ} 34^{\prime} 55^{\prime \prime} \mathrm{S}, 65^{\circ} 23^{\prime} 50^{\prime \prime} \mathrm{W}\right)$ there is an urgent need of debris flood hazard assessment and mitigation. The Tilcara alluvial fan has been built by the Huasamayo Stream, under arid environmental conditions, in a compressive tectonic context (Sancho et al., 2008). At present, the active depositional lobe is constrained by artificial levees in a narrow sector of the fan. Its ephemeral activity often results in floods that affect housing and infrastructures built in the vicinity of the preferential path of the stream.

The Huasamayo Stream is a tributary of the Rio Grande, which flows in a narrow mountain valley located in the Province of Jujuy in northwest Argentina, $1500 \mathrm{~km}$ north of the Capital Buenos Aires. This valley, named Quebrada de Humahuaca, was followed by a major cultural route, the Camino Inca, which starts from the Rio Grande springs located in the desert plateau of the High Andean lands towards 
its confluence with the Rio Leone, $150 \mathrm{~km}$ southwards. Since the time of hunters and gatherers, the valley has been a natural route for people, goods and ideas. For these reasons, since 2003, it has been included in the UNESCO Word Heritage list. As several mass wasting processes affect the Quebrada de Humahuaca, limiting its development and posing risk to hamlets, infrastructures and to the peculiar landscape of the area, UNESCO itself has encouraged Argentina "to carry out an environmental assessment of the proposed flood defence project in order to gauge its impact on the outstanding universal value of the Valley". In fact, besides Tilcara, almost 20 villages are located along the valley, but the population is significantly decreasing, also as a secondary consequence of the high frequency of mass wasting phenomena that cause relevant damage to structures and infrastructures, halting traffic on transportation routes. Moreover, these mass movements threaten the farming activities, exploiting the terraces along the valley floor, with the effect of reducing the area of the land available for cultivation and therefore the sustenance of the population.

In particular, landslides and debris floods are the main hazardous phenomena affecting the slopes and the valley floors, inducing also serious consequences on the erosion and sedimentation activity of the Rio Grande (Chayle and Wayne, 1995; Cencetti et al., 2001; Cencetti, 2008). Most of these events occur on the Quaternary alluvial fans that are significant landforms within the Quebrada de Humahuaca landscape. Among these, the Tilcara alluvial fan represent an interesting geomorphological asset, as it incorporates spectacular morphostratigraphic features; at the same time, its evolution is a major natural hazard threatening human settlements and activities.

Alluvial fans are fan-shaped geomorphological features progressively generated by deposition of eroded sediment (NRC, 1996). Since ancient times and all over the world, alluvial fans have been occupied by human settlements and related economic activities, because of mild slope and smoothness of topography, land fertility and relative closeness to rivers (Schick et al., 1999). Especially in high mountain environments, alluvial fans are exposed to a number of natural hazards, mainly related to mass transport and erosion phenomena. In particular, debris floods are hydrological masstransport phenomena characterized by gently sloping deposition areas and massive bedload transport, with limited boulder transport and deposit thickness (Aulitzky, 1980). The inherent velocity and energy of these phenomena and, to some extent, their unpredictability can cause loss of lives and significant economic damage if the material cannot be contained in the main stream, eventually inundating parcels, buildings and roads. As the triggering and subsequent evolution is very rapid, it is generally quite difficult to implement effective monitoring devices and related thresholds and early warning systems. As a consequence, structural risk mitigation has become a priority and the classic approach is to implement control works to constrain the stream in a sector of the fan or to limit and filter the sediment that can be transported during an event.

However, in areas where there is a significant anthropic pressure and particularly in developing countries, the need for exploitable land may lead to underrate the risk, to build insufficient countermeasures and not to respect buffer zones (Burton and Kates, 1964; Blaikie et al., 1994). Moreover, developing countries necessarily place higher priority on food production, leaving fewer resources for sustainable risk management procedures (Clarke and Munasinghe, 1995). These factors increase the vulnerability and, in order to plan effective mitigation works, it is important to consider the socio-economic context of the region prone to natural hazard (Alcàntara-Ayala, 2002).

The control structures must be dimensioned for high intensity events to guarantee a high degree of safety, especially if the land use limitations, are removed in case of ongoing urbanization; actually, these kind of countermeasures are expensive and the political pressure may sometimes lead to underestimate the risk and install buffer solutions. Sometimes, in order to finance control works, it may be possible to rely on private investments, especially if the frequency of disaster events is sufficiently high (Keefer, 2009).

Moreover, the ongoing climate changes can result in more frequent events. In particular, the El Niño Southern Oscillation (ENSO) climatic phenomenon has been widely referred to because of its impact on economies and human activities in developing countries, also as a consequence of more intense mass wasting phenomena. The relationship between interannual atmospheric and oceanic circulation oscillations, controlling precipitation regime and landslide activity phases, has been observed in these areas. In Latin America, the temporal distribution and frequency of landslides triggered by precipitation seem to be strictly conditioned by the ENSO climatic cycle (Moreiras, 2005), and also at longer time scales (Trauth et al., 2003). It can induce enhanced precipitation, leading to an increase in pore-water pressure in soils, lateral scouring of rivers and over steepening of hillslopes, eventually resulting in shallow failures and large mass movements.

At present, a specific hydrological study of the Tilcara area is part of the integrated and multidisciplinary investigation plan set up in order to document, assess and mitigate hydrogeological hazards. The research activity includes geological and geomorphological investigations together with the analysis of social and economic aspects in order to assess the impact of mitigation measures on the urban environment.

\section{Study area}

\subsection{Alluvial fan processes and dynamics}

Alluvial fans are depositional landforms produced where channels enter a zone of reduced stream power (Harvey, 
2004). This situation is found at mountain fronts and at tributary junctions, where the sediment load is normally deposited. The evolution of these landforms are driven by the long-term evolution of the landscape, with reference to the tectonic regime and the rate of uplift, and occur in all climatic setting. In particular, fan morphology is directly related to water and sediment supply, which in turn is controlled by climate. Alluvial fans can be classified in debris-flow and fluvially-dominated, on the basis of the primary process that delivers sediments to the fan itself. The predominance of one process on the other is witnessed by either sediment type and texture, or surface morphology; it depends on the catchment characteristics and on the water and sediment mixture rheology. It is clear that debris flow are more common where sediment availability is high and in steep catchments, whereas fluvial processes prevail in large, less steep basins (Harvey, 2004).

Debate occurs over the relative roles of tectonics, base level changes and climate in governing the evolution of alluvial fans, even if climate is meant to play a major role in fan dynamics, either in dry or in humid regions (Bull, 1991).

In arid environments alluvial fans are composed of loose clastic materials deposited during extreme magnitude-low frequency flood events, originating in the upper sector of the catchment (Graf, 1988). Frequently, the widening of the channel and its eventual avulsion can convey the watersediment mixture to large areas of the fan; as a result, the return period in each area may vary, exceeding many decades.

\subsection{The Tilcara alluvial fan}

The study area is located in northwest Argentina near the border with Bolivia, in the Quebrada de Humahuaca valley, where the Rio Grande de Jujuy river flows. The elevation of the valley floor spans from $3440 \mathrm{~m}$ a.s.l. near the village of Iturbe to $1350 \mathrm{~m}$ where the Rio Grande flows in the Rio Reyes; the valley width ranges from $100 \mathrm{~m}$ up to $3 \mathrm{~km}$ (Fig. 1). The valley, which has an asymmetrical profile, is surrounded by Sierra Agular and Chani on the west side, which exceeds $6200 \mathrm{~m}$ allowing for the presence of permanent glaciers, and the Sierra Zenta-Tilcara on the east side, which has lower peaks about $5000 \mathrm{~m}$ high, with no glaciers.

The Rio Grande is characterized by scattered discharge values, mainly due to climatic variability. At the station of San Juan, $180 \mathrm{~km}$ downstream from the springs, the maximum measured discharge is $358 \mathrm{~m}^{3} \mathrm{~s}^{-1}$ and the minimum $3 \mathrm{~m}^{3} \mathrm{~s}^{-1}$.

From the geological point of view the Quebrada de Humahuaca is one of several intramontane reverse-fault bounded basins of the Cordillera Oriental thick-skinned fold and thrust belt. In the study area, folded, faulted and jointed Precambrian and Cambrian geological units prevail. Puncoviscana Formation is a Precambrian low grade metamorphic unit with slates and phyllites. The Cambrian rocks, belonging to the Meson group, constitute the principal core of

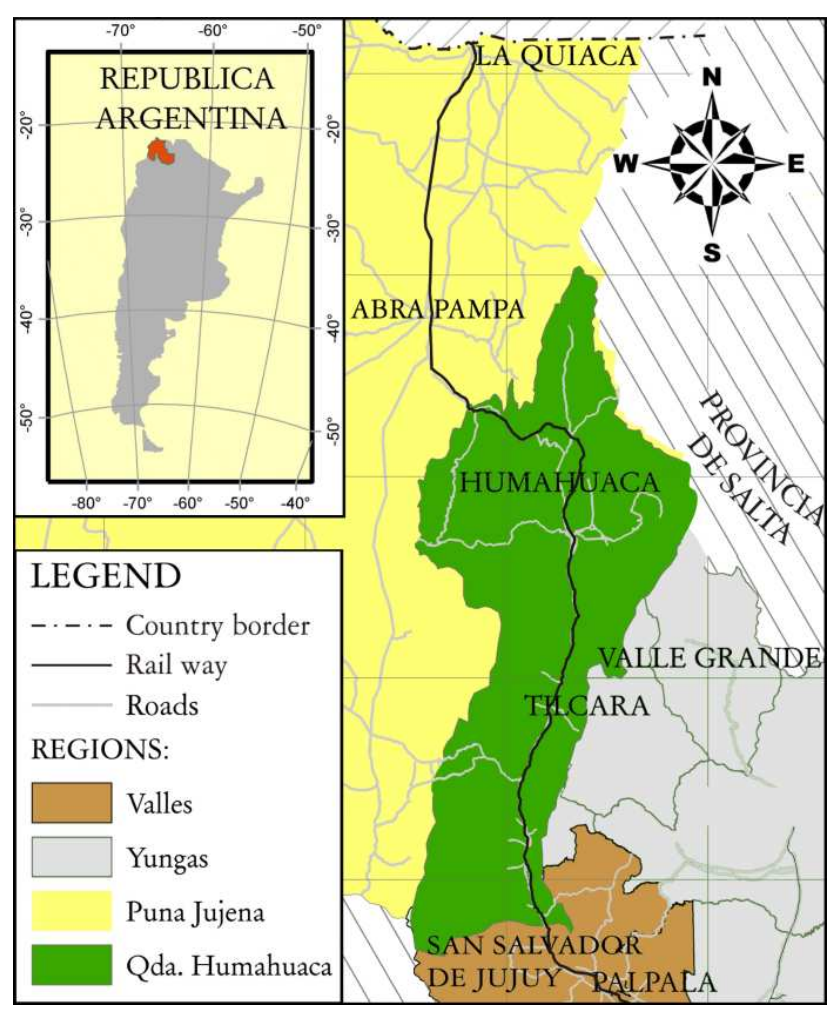

Fig. 1. Geographical setting. The Quebrada de Humahuaca region in the Province of Jujuy.

the ridge (the sierra). These are multicolored orthoquarzites and quarz-rich arenites (Ramos et al., 1967; Turner, 1970; Amegual and Zanettini, 1974). The general structure is related to a homoclinal fold, with $\mathrm{N}-\mathrm{S}$ direction, dipping eastward. Regional N-S faults have produced the uplift of large areas and determined the incision of $\mathrm{N}-\mathrm{S}$ valleys, such as the Quebrada de Humahuaca (Turner, 1970; Mon and Salfity, 1995).

Some tectonic lineaments, mainly strike slip faults trending SE-NW, conjugate to principal thrusts (Salfity et al., 1984), drive the drainage pattern of the tributaries of Rio Grande, like Huasamayo and Huichara streams.

Over the bedrock, an extensive Quaternary cover is found, which was generated by gravity processes acting in the upper part of the slopes, together with alluvial phenomena in the valley bottom. The morphology of this area is strictly controlled by lithological and structural features of the rock masses and by ancient and active tectonics (Marcato et al., 2009). Mass wasting phenomena are in fact conditioned by the notable tectonic uplift of the area (Chayle and Aguero, 1987). The present-day geomorphological evolution of the Quebrada de Humahuaca is largely controlled by the mobilization of the thick deposits generated by the physical weathering of the rock masses. In particular, the action of severe frost shattering in periglacial conditions has also a major role in the production of an extensive debris cover. 
The marked asymmetry of the valley flanks conditions the type and activity of processes and landforms. On the eastern flank two terraces formed by Rio Grande can be found, together with huge incised alluvial fans generated by the different tributaries originating from the eastern cordillera. The deposits are represented by poorly consolidated coarse sediments, easily involved in mass transport phenomena. These deposits are mainly organized in terraces, pediment cover units and alluvial fans (Robinson et al., 2005) (Fig. 2).

The Rio Grande basin has a mountain arid climate type, with high intensity and irregular summer storms and cold winters, especially in the central part of the valley, where the village of Tilcara is located. Here, the annual average rainfall is $136 \mathrm{~mm} \mathrm{yr}^{-1}$ as a consequence of the orographic barrier formed by the oriental peaks, which prevents the crossing of the cloud systems generated from the Atlantic anticyclone. Moreover, nearly all precipitations occur during the summer season, with meteorological events that can be very intense. Unfortunately, no continuous data are available on precipitation regime. At present, the only available climatic data in Tilcara is the average precipitation on a monthly basis (the maximum is in January, with $42 \mathrm{~mm}$ on a 1934-1990 dataset).

The vegetation cover of the basin, consisting mostly of xerophytes, is scarce; therefore, the soil can undergo intense superficial erosion during high intensity rainfall events.

The Tilcara alluvial fan has an area of $5 \mathrm{~km}^{2}$, with a drainage catchment in the order of $120 \mathrm{~km}^{2}$. The Huasamayo River is the main feeding channel, on a length of $12 \mathrm{~km}$ and a difference in altitude of more than $2000 \mathrm{~m}$. Therefore, the longitudinal profile is short and the slope is relatively high, being in the order of $10-11^{\circ}$ (Fig. 3).

The geomorphological evolution of the Tilcara alluvial fan is characterized by a complex segmented development pattern (Sancho et al., 2008). Remnants of old evolutionary stages are recognizable; nowadays, they are in a higher position with respect to the actual thalweg of the Huasamayo stream, due to compressional tectonic movements. The Quaternary deposits are characterized by conglomeratic and sandy facies (Sancho et al., 2008). The conglomerates are mainly clast-supported, with a sand matrix and a weak cementation. The sandy facies are arranged in lenticular geometries. The morphostratigraphic features suggest that each fining-upward sequence begins with a debris flood, eroding the base of the channel and depositing sediments as the energy of the flow decreases. The entrenchment of the channel allows the sand lenses to fill it. Normal sedimentation phases occur between two surge events in the distal part of the fan (Sancho et al., 2008). The terraced arrangements of these deposits, constituted by poorly consolidated materials, form a nearly inexhaustible sediment reserve that can be transported by flooding events.

Present-day fan activity is mainly due to debris floods, which develop as very rapid surging flow of water that gains energy in the steep channel therefore transporting a great amount of sediments.

\section{Hydrogeological hazard and risk in the Tilcara alluvial fan}

\subsection{Hydrogeomorphic processes in the Huasamayo stream catchment}

The high average slope of the basin generates a system with great potential energy, that can lead to intense alluvial phenomena. At the same time, the occurrence of slope failures in the upper part of the Huasamayo catchment can cause the formation of small landslide dams and frequently hyperconcentrated flows are generated as a consequence of dam breaching. More often, it is the shear stress induced by the high velocities of the water itself that causes debris floods. In fact, from the basin the water is collected in a narrow, steep rock canyon called Garganta del Diablo; then the channel cuts into old deposits, with sufficient energy to mobilize a great amount of sediment from the lateral scarps and from the channel bottom, entraining the debris and transporting it until the channel opens in the active fan. Here the flux starts to decelerate, depositing its load.

At the beginning of the eighties, in order to limit the area subject to flooding to the most active depositional lobe and to protect the urbanized portion of the Tilcara alluvial fan, deflection walls have been constructed. Unfortunately, in 1984 an high magnitude event broke the artificial levees, damaging more than 30 houses (Azarevich et al., 1999). Moreover the flux-constraining approach, limiting the spreading of the flood, has caused massive aggradation during the years, therefore requiring the construction of higher levees, with increasing maintenance costs. These processes have generated a hanging channel, that in some places could be up to $5 \mathrm{~m}$ above the houses nearby (Fig. 4). It is clear now that the risk, instead of being reduced, has been increased by the installation of the deflection levees and that a different approach has to be considered, to reduce the hazard and the risk for the Tilcara inhabitants.

The documentation of past events is inadequate to perform a sound hazard assessment. In particular, preferential paths and inundated areas haven't been mapped. Therefore, the deposit map and an evaluation of the deposited volume are not available, together with pre- and post-event channel geometries. As a consequence, at this stage of the research, both semi-empirical scaling relationships (Griswold and Iverson, 2008) and dynamic modeling (Hungr, 1995) cannot be applied in order to obtain hazard maps on the alluvial fan.

Concerning the main valley, pushed westwards by the telescopic evolution of the alluvial fan, the Rio Grande was forced to bend and therefore to erode his alluvial terraces on the right bank, where the National Route 9 stretches. The road suffered from damage due to a number of slope failures, 


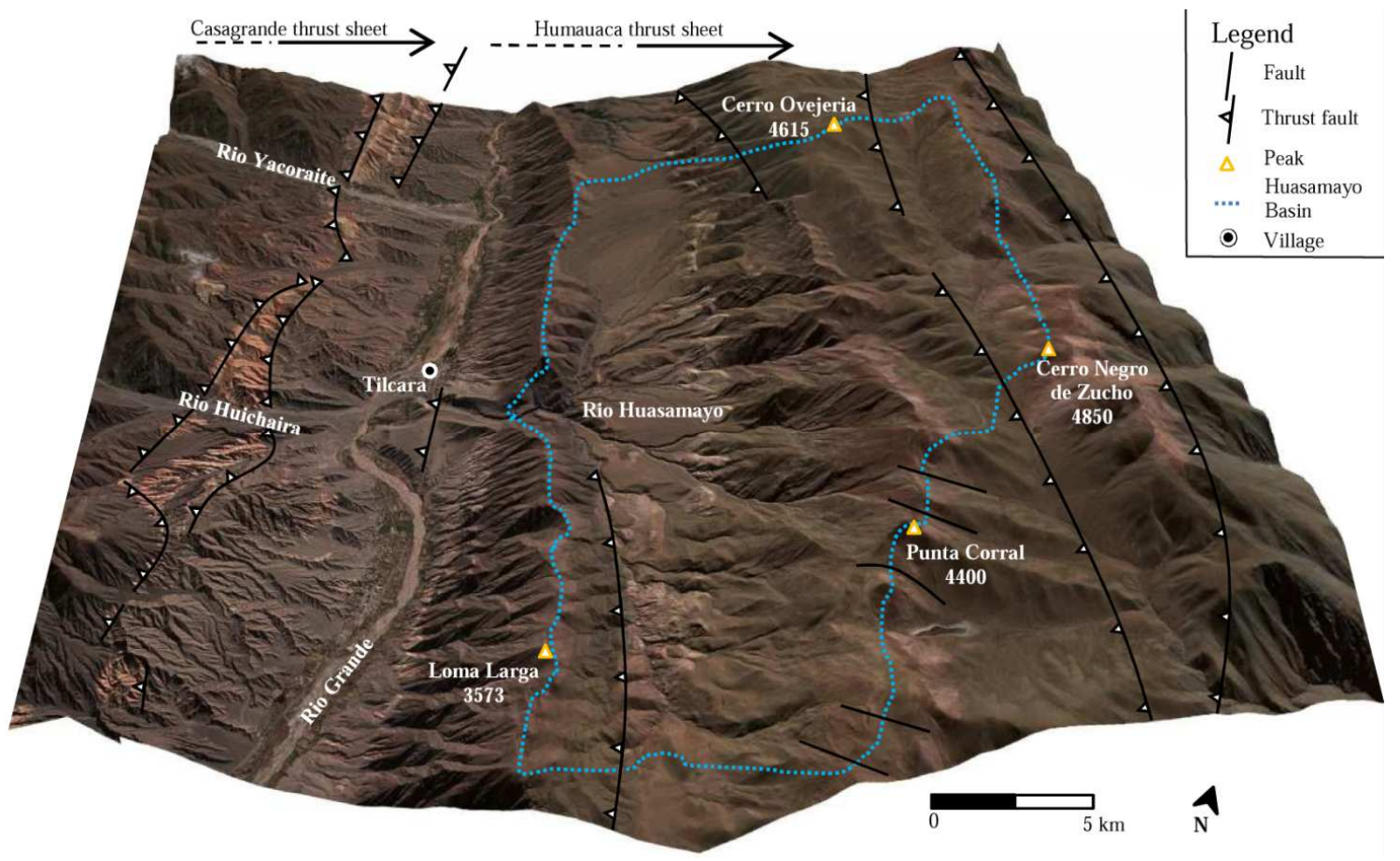

Fig. 2. Structural sketch map of the area (after Sancho et al., 2008). Image source: Google Earth.

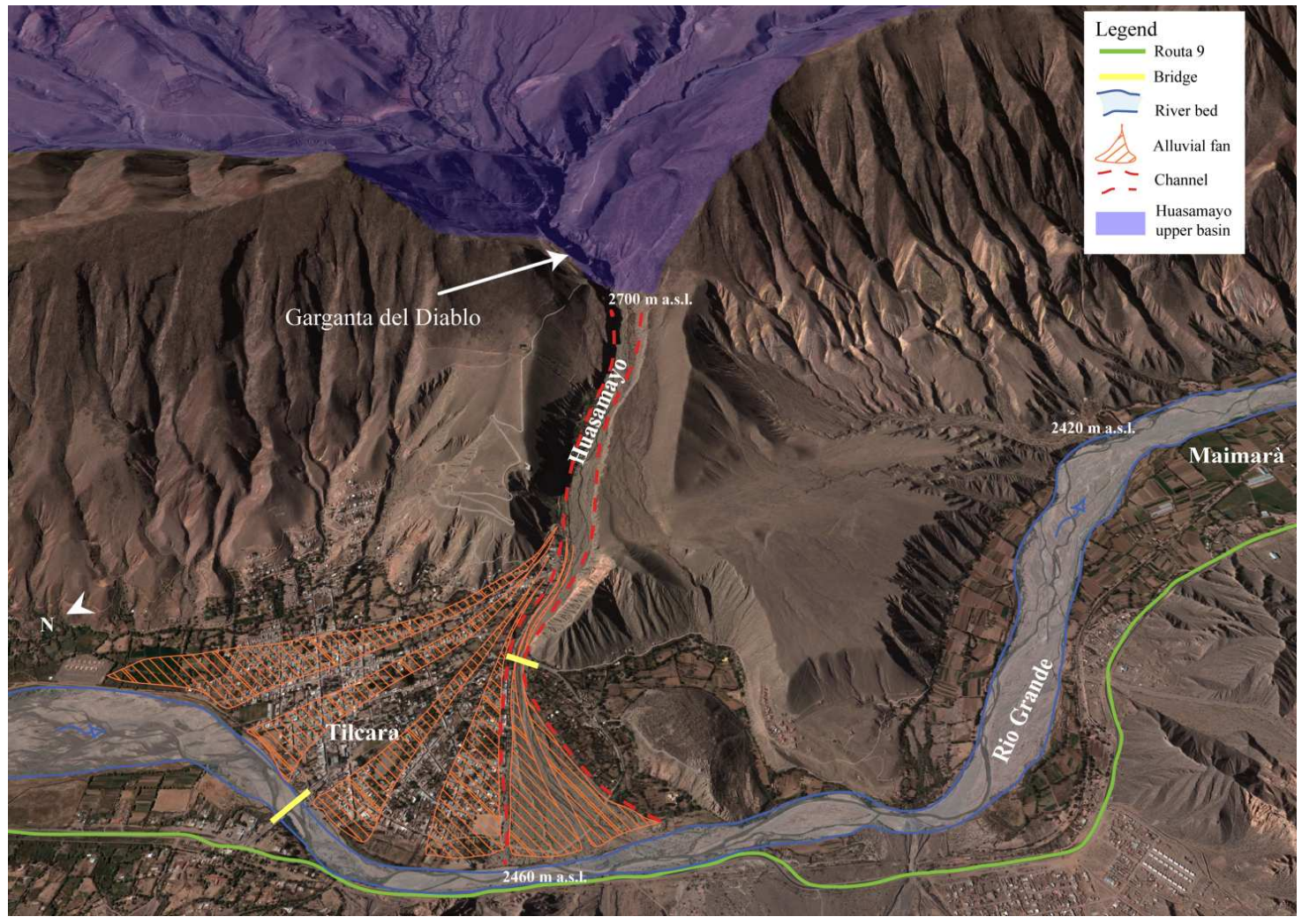

Fig. 3. The Tilcara alluvial fan. The Huasamayo Stream catchment is visible in the background. The location of Tilcara village with reference to the active depositional lobe is represented. Note the location of the National Road, which can be involved in flooding events. Image source: Google Earth. 


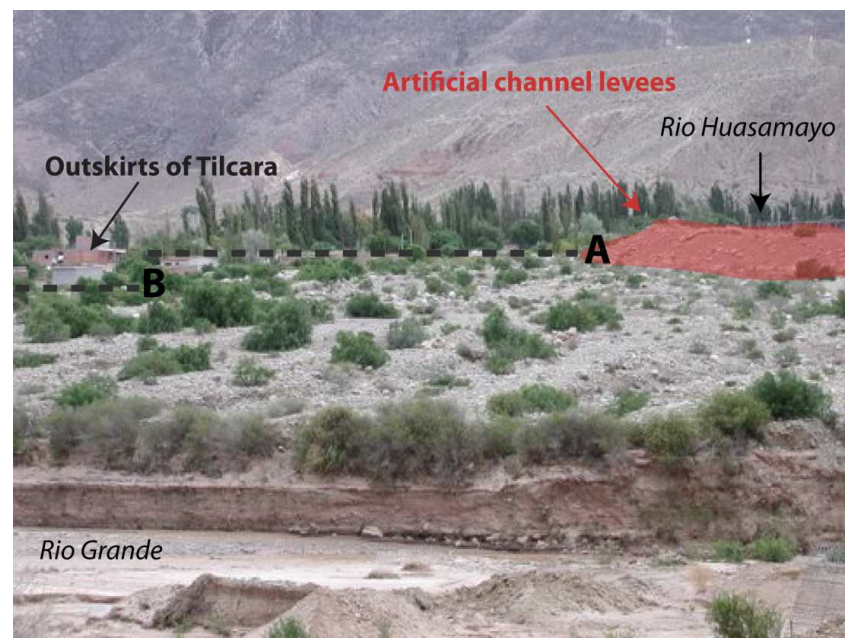

Fig. 4. At present, the thalweg level (A) is up to $5 \mathrm{~m}$ higher than the ground level (B) in the outskirts of Tilcara Village.

mainly caused by toe erosion; at that time engineering works were designed and gabion walls were installed. Furthermore, due to the Huasamayo periodical floods, the Rio Grande was partially dammed in 1998 and 1999, Routa 9, farming areas and a camping site were flooded during these events.

The damming of the Rio Grande has become a major hazard since the floodplain is narrowing due to the alluvial fan development; downstream the confluence, the hamlet and its ancient and important farming activities of Maimarà lay just a few meters above the thalweg therefore in a risky position in the event of a major dam breach.

\subsection{Socio-economical setting and vulnerability issues}

In the Quebrada de Humahuaca, the hydro-geological processes are strictly related with the socio-economical setting. The population of the Department of Tilcara is of 10000 inhabitants. At present, the demography is changing, as campesiños are leaving the valley, also as a consequence of the high frequency of mass movements that damage parcels, structures and infrastructures. For example, the Ruta Panamericana National n. 9, the main road connecting Argentina with Chile and Bolivia, is affected by landslide phenomena, and the connection and the transport of goods can be frequently interrupted. Even the strategic railway Ferrocaril General Belgrano was also abandoned in 1992, due to increasing maintenance costs. At the same time, mass transport phenomena jeopardize cultivated fields, reducing the land available for farming, but they can also partially or totally dam the Rio Grande causing flooding. In this scenario the farming activity are struggling to survive and sustenance for the local population is becoming more expensive.

At the same time, the number of tourists visiting the Quebrada is noticeably increasing, thanks to the declaration of UNESCO, that included the site in the World Cultural Her- itage list. During summer season, due to tourism, the population can reach 20000 units and the demand for new building plots to assign for hotels and resorts is very high. Moreover, people are coming from other parts of Argentina to work for the touristic industry. As no urban planning is available in the main villages, barrios de emergencia, have been constructed in the floodplain or on alluvial fans to accommodate the new workers. The hydrogeological risk in these areas is very high and, due to the chronic lack of funds, the countermeasure works that have been constructed are generally underestimated and are also affecting the sediment transport rate of the basin. The engineering works tend to solve the problems locally, most of the times losing the big picture: often, their long-term impact turned out to be damaging (Chayle and Wayne, 1995). For example, some deflection walls that have been built are narrowing the tributary channels thus exposing risk for other boroughs, by increasing aggradation locally. On the other side fields previously devoted to agriculture have been purchased by investors for building touristic facilities, therefore impacting the same "cultural landscape", as UNESCO calls it, the tourists are coming to visit (Repiso et al., 2007).

In Tilcara area, the urbanized portion of the alluvial-fan is $1.3 \mathrm{~km}^{2}$ (Fig. 5) and for the local population, the chance to build on the active sector of the fan, which has an area of $0.2 \mathrm{~km}^{2}$, is particularly appealing.

It is possible to roughly estimate that the new allotments could accommodate almost 1500 people if the local building typology and density is maintained. The economic outcome for the village could be extremely positive and this is an important element to consider when evaluating different possible mitigation strategies. The income generated by tourism is virtually the only source of money for financing the remediation works. A building compensation plan could be an excellent resource for fund a radical risk mitigation for the whole Tilcara village, since relocating is almost impossible. It is important to underline that the urbanization of the area is an almost inexorable process and therefore it is necessary to design a compromise solution to meet the safety, economic and environmental requirements.

\section{Risk mitigation}

\subsection{Risk mitigation issues in natural and cultural heritage sites}

In general, in the management of natural and cultural heritage sites, experts and planners should cooperate and support public administrations in order to ensure long-term conservation goals and the safety for both population and visitors, carrying out:

- the documentation of past and present hazard and risk conditions; 


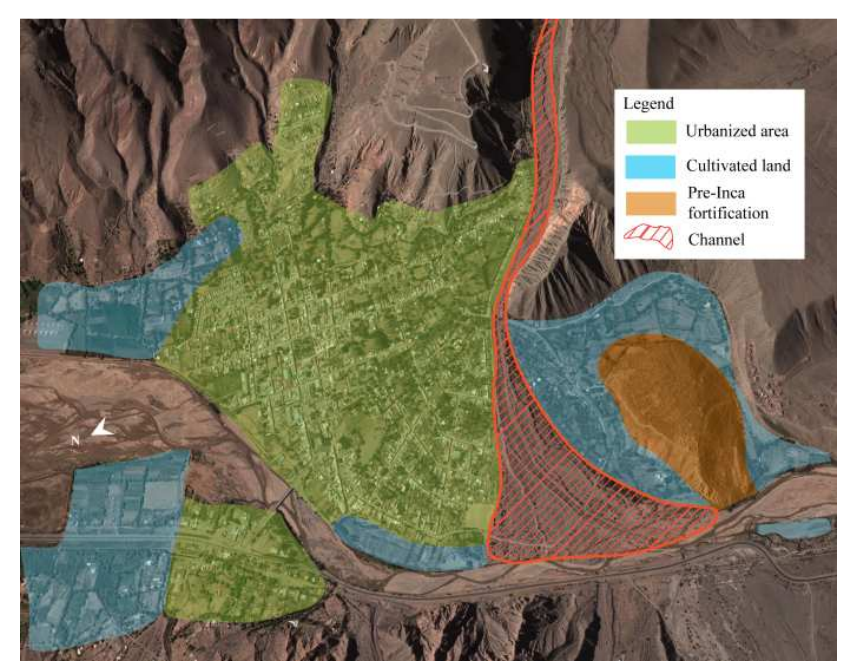

Fig. 5. Land use in the Tilcara alluvial fan. Image source: Google Earth.

- the evaluation of conservation issues in the context of the geomorphological processes acting in the area, including risk and impact implications;

- eventual design of countermeasures, both structural and non-structural, minimising environmental and visual impact;

- correct information about the natural hazards for population and visitors.

All the interventions should be designed respecting low environmental impact issues. Suitable remedial measures should be chosen paying attention to visual intrusion in scenic areas or to visual impact on the natural conditions of the site (i.e. shapes, colours, dimensions, materials etc.).

In this specific case, some possible low-impact solutions could employ gabions built using local materials, covered by rock blocks simulating local structures and building practices.

\subsection{Possible risk mitigation actions in Tilcara}

The assessment of debris flood hazard and hazard mapping can be performed by means of a number of different methods able to simulate the flow evolution and to predict the flow path and inundated areas on alluvial fans. In these procedures, the documentation of past events is of paramount importance, both for the application of empirical and semiempirical equations and for the calibration of mathematical models.

At present, no continuous records of rainfall and discharge are available for the Huasamayo river basin, therefore it is not possible to perform a general hydrological study of the basin. Moreover, the aggradation and erosion phenomena in the channel have not been mapped at a detailed scale after major past events. Even though it is unquestionable that these studies are mandatory in order to design countermeasure works (Marchi et al., 2010), though the analysis of landforms and the description of the events given by the local population it is possible to outline two possible mitigation scenarios for the village of Tilcara. The first scenario is conservative and it consists in the periodical removal of the material accumulating in the alluvial fan, and in the maintenance and reinforcement of natural and artificial levees (see Fig. 3). Even though in developed environments this solution could be the most cost-effective and less landscape impacting, in a socio-economical situation like in the Quebrada de Humahuaca, it would be extremely difficult to implement. In fact, since there is little municipal control over new constructions, the anthropic pressure on the fan would probably lead to a progressive narrowing of the active depositional lobe, with increasing hazard and risk for the population. Besides, since the public funds set aside for engineering measures are limited, the risk is that the magnitude of the event for which they are designed could be inadequate to guarantee a sufficient level of safety; in this sense, the 1984 episode is sadly illustrative of this tendency. Moreover, in case of two or more subsequent events, the channel would not be effective.

The second approach is extremely radical, but it could be an opportunity to solve definitively the hazardous conditions of Tilcara. An artificial channel could be designed on the left bank of the Huasamayo River in order to divert the floodwaters laterally, preventing them from entering the sediment laden deposits of the fan (Fig. 6), (L. Marchi, personal communication, 2011). At present this is just a hypothesis, as studies on the project discharge and on the rheology of the water and sediment mixture that can be transported from the upper part of the basin are lacking. Anyway, given the fact that areal-type measures are not feasible in arid environments, the diversion of stream channel at its outlet from the upper catchment appears to be a viable option.

The channel entrance could be placed at $2745 \mathrm{~m}$ a.s.l., at the exit of the narrowest part of the Garganta del Diablo where the natural average thalweg slope is $25 \%$. Then, across the alluvial bank, the channel would enter at $2715 \mathrm{~m}$ in a preexisting gully, and from there the water would flow naturally towards the Rio Grande. The channel would be $550 \mathrm{~m}$ long with a slope of $5 \%$ in the first track, which would be $400 \mathrm{~m}$ long, and $6.5 \%$ in the rest of its course. If we consider a trapezoidal section for the channel with a $10 \mathrm{~m}$ base and $30^{\circ}$ scarps, we can roughly estimate a volume of $500000 \mathrm{~m}^{3}$ to be removed. To assure that the artificial channel would not be affected by avulsion, the debris would be placed at the outlet of the Garganta forming a protective dam immediately downstream of the artificial channel in order to direct the flow into the artificial channel itself. Given that the excavating material would be poorly consolidated sand and gravel, the digging and transport process could be performed simply by caterpillars, keeping the construction costs 

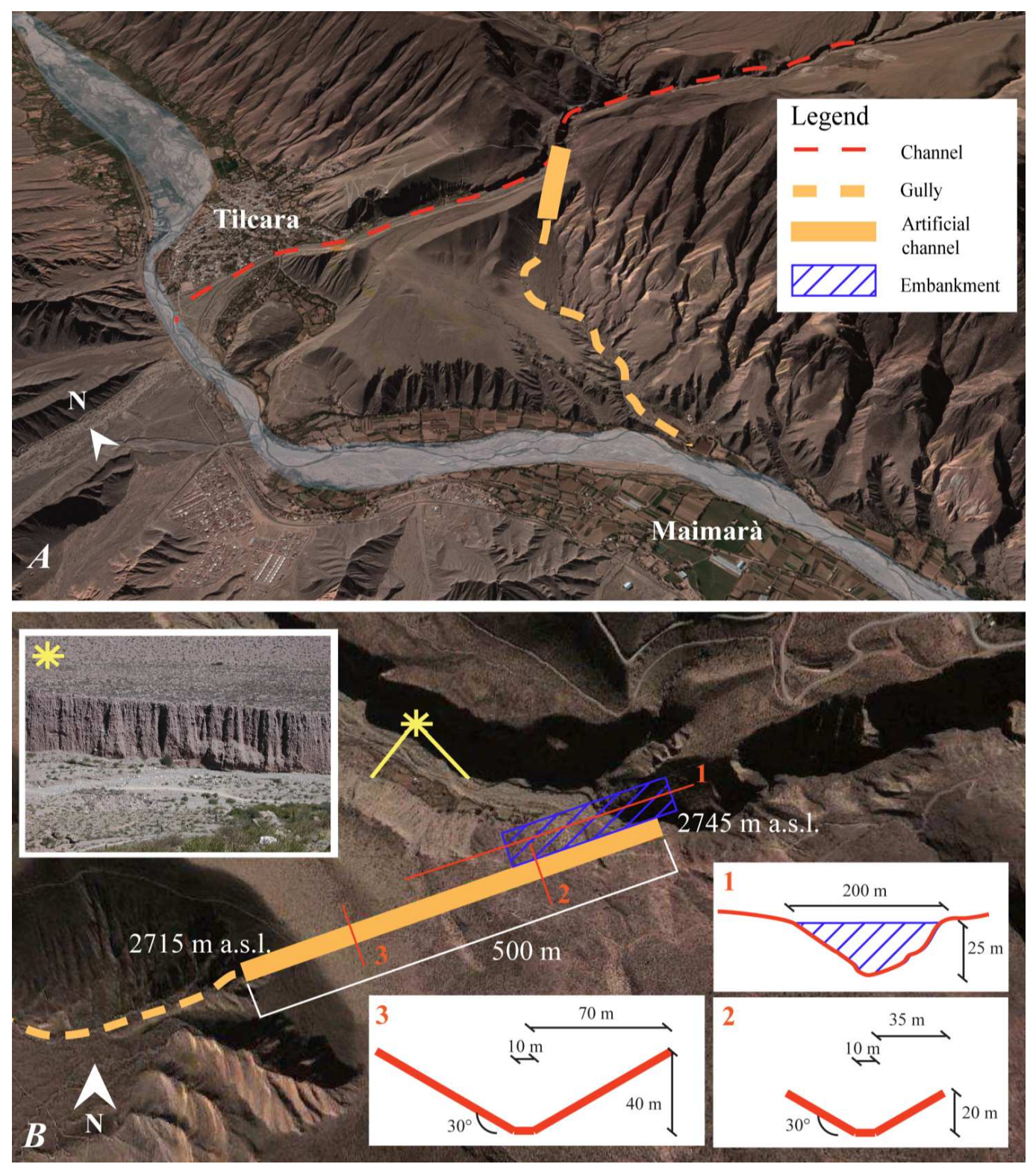

Fig. 6. Sketch of the proposed countermeasure. (A) Location of the diversion channel. (B) Cross sections of the artificial channel and picture of the material to be excavated. Image source: Google Earth.

relatively low. Moreover, the financial costs of the engineering work could be carried by the investors that would exploit the Tilcara alluvial fan.

In the design of such a structure, some issues must be taken into account, besides the need of a low environmental and visual impact. Firstly, in order to assure an adequate degree of confidence the deflection dam must be sufficiently high to avoid overtopping even in case of multiple, successive events; in fact, sediment accumulated upslope of the embankment could decreases the total freeboard of the structure. For this reason the estimate height of the dam is $25 \mathrm{~m}$ above the thalweg. The feasibility of such an embankment has to be analysed and designed in further studies, considering both hydraulic and geotechnical properties of the soils. Moreover, the margin of safety has to be extremely high because the risk of overflow and/or the breaching of the protective dam could in the end cause higher damage with respect to the same flood event in the natural state.

To design these control works, an estimate of the maximum flood event is required, assessing peak discharge and total flow, sediment yield and composition. The peak discharge is needed to design the channel geometry, i.e. the cross-section and the slope. Sediment characterization is necessary to estimate the amount of deposited material to be expected along the channel path and especially at the junction of the natural stream with the artificial channel. In order 
to design properly the countermeasure works, considering the $30^{\circ}$ bending angle and even more the sudden change of slope at the junction, a 3-D hydraulic and dynamic model will be mandatory to estimate the behavior of the flow and the probability of obstruction and spill of the flood out of the channel or the gully.

Characterization of groundwater flow is also needed. In fact, monitoring and modeling of groundwater tables and flows are mandatory during design and construction phases of check dams, embankments and artificial levees. At this stage, specific data are lacking. Nonetheless, in this arid region, considering the regime and scarce quantity of precipitation, the nature of infiltration and pore water pressure build up is strongly transient, considering the grain size and sorting of deposits, which are relatively permeable. Moreover, in tributary valleys, no permanent inflow by rivers and glacier is present and only small perched aquifers are expected. This is also testified by the vegetation cover, which is very sparse in the whole catchment. Therefore, these issues can be considered of minor importance both for the long- and short-term stability of the embankment. Anyway, during the design, severe conditions have to be accounted for, with reference to pore pressure build up during storms and rapid drawdown after a debris flood event.

Another important aspect that has to be considered is the effect of the flow diversion further downstream, at the confluence with the Rio Grande (Fig. 6). In fact, the outlet of the natural gully lays in front of the village of Maimarà on the other bank of Rio Grande river and in the further phase of studies it will be essential to assess the stability of the Maimarà river bank, considering that erosion phenomena may occur (Best, 1986). It might be necessary to build a protection wall, even though the angle of confluence is rather small.

\section{Conclusions}

In developing countries, the effectiveness of mitigation works has to be evaluated considering the socio-economic context, the environmental impact and the effects of climate changes.

The area of Tilcara, in the Quebrada de Humahuaca, is characterized by huge volumes of poorly consolidated debris, that might be mobilized by mass wasting phenomena, namely landslides and debris floods. In particular, debris floods phenomena cause damage to infrastructures and agricultural activities and also to the cultural asset of the Camino Inca, which stretches along this valley and is included in the UNESCO World Cultural Heritage (UNESCO, 2003).

In this framework, a mitigation strategy aimed at avoiding potential damages should be implemented in order to preserve the natural condition of this fragile environment and its population. Given this situation, two opposite needs have to be guaranteed: the preservation of the peculiar landscape as it is, without further human interventions, and the protection of populations and their goods, in order to provide them future chances of development.

In arid and high mountain environments, low-impact areal measures such as terracing and revegetation are not feasible. At the same time, the construction of embankments and ditches to protect the built-up area cannot be the ultimate solution, especially where anthropic pressure is high and continuous maintenance is needed. Hence, structural watershed management has to be considered.

In Tilcara, a viable option is to divert the stream channel at its outlet from the upper catchment. This solution is impacting and relatively expensive, but the resulting environmental and landscape drawbacks can be accepted considering that the protection of highly valuable sites is guaranteed and that the means of financing the countermeasure works could be found in private investors. In order to minimize the expected impacts, the proposed remedial measures should employ available technologies and local hand, incorporating low environmental and visual impacts issues. This approach to the mitigation of mass wasting phenomena affecting the Tilcara alluvial fan should bridge the gap between the need of preservation, the request of safety and the yearning for development of the local population, keeping in mind UNESCO recommendation.

Acknowledgements. The Authors wish to thank two anonymous reviewers and the Editor for their suggestions, which have helped to improve the earlier version of the manuscript. We are thankful to Lorenzo Marchi for the constructive discussions of debris flood processes and possible mitigation actions. The research was funded by National Research Council of Italy, International short mobility Program.

Edited by: F. Luino

Reviewed by: two anonymous referees

\section{References}

Alcàntara-Ayala, I.: Geomorphology, natural hazards, vulnerability and prevention of natural disasters in developing countries, Geomorphology, 47, 107-124, 2002.

Amegual, R. and Zanettini, J. C.: Geologia de la quebrada de Humahuaca entre Uquia y Purmamarca (provincia de Jujuy), Revista de la Asociacion Argentina, 29, 30-40, 1974.

Aulitzky, H.: Preliminary two-fold classification of debris torrents, Interpraevent, Bad Ischl, Austria, (translated to English by G. Eisbacher), 4, 285-309, 1980.

Azarevich, M., Novara, M., Armella, M., Deus, R., and Sánchez, M. C.: Geomorfología de la región de Tilcara, Jujuy, XIV Congreso Geológico Argentino, Actas II, 31-34, 1999.

Best, J. L.: The morphology of river channel confluences, Prog. Phys. Geog., 10, 157-174, 1986.

Blaikie, P., Cannon, T., Davis, I., and Wisner, B.: At Risk: Natural Hazards, People's Vulnerability, and Disasters, Routledge, London, 320 pp., 1994. 
Bull, W. B.: Geomorphic Responses to Climatic Change, Oxford University Press, Oxford, 1991.

Burton, I. and Kates, R. W.: The perception of natural hazards in resource management, Nat. Resour. J., 3, 412-441, 1964.

Cencetti, C.: River Dynamics in the Cordillera Oriental of the Andes (northwestern Argentina), Italian Journal of Engineering Geology and Environment, 1, 151-184, 2008.

Cencetti, C., Rivelli, F. R., Tacconi, P., and Viglione, F.: La Quebrada de Humahuaca (Bacino del Rio Grande de Jujuy, Argentina nord-occidentale): caratteristiche di un bacino di ambiente andino, L'Universo, 4, 496-514, 2001.

Chayle, W. and Aguero, P.: Caracteristicas de la remocion en masa en la Cuenca del Rio Grande (quebrada de Humahuaca, Jujuy), Revista del Instituto de Geologia y Mineria, San Salvador de Jujuy, Universidad Nacional de Jujuy, 7, 24-31, 1987.

Chayle, W. and Wayne, W. J.: Impact of erosion, mass wasting, and sedimentation on human activities in the Rio Grande Basin, Jujuy Province, Argentina, Environ. Eng. Geosci., 1, 403-416, 1995.

Clarke, C. and Munasinghe, M.: Economic aspects of disasters and sustainable development: an introduction, in: Disaster Prevention for Sustainable Development, edited by: Munasinghe, M. and Clarke, C., Economy and Policy Issues, IDNDR and the World Bank, Washington, 1-10, 1995.

Graf, W. L.: Fluvial Processes in Dryland Rivers, Springer-Verlag, New York, 1-387, 1988.

Griswold, J. P. and Iverson, R. M.: Mobility statistics and automated hazard mapping for debris-flows and rock avalanches, US Geological Survey Scientific Investigations Report 5276, 2008.

Harvey, A.: Alluvial fans, in: Encyclopedia of Geomorphology, edited by: Goudie, A. S., Routledge, London, 15-19, 2004.

Hungr, O.: A model for the runout analysis of rapid flow slides, debris flows and avalanches, Can. Geotech. J., 32, 610-623, 1995.

Keefer, P: Disastrous consequences: the political economy of disaster risk reduction, Joint World Bank Report - UN Project on the Economics of Disaster Risk Reduction, 2009

Marchi, L., Cavalli, M., and D'Agostino, V.: Hydrogeomorphic processes and torrent control works on a large alluvial fan in the eastern Italian Alps, Nat. Hazards Earth Syst. Sci., 10, 547-558, doi:10.5194/nhess-10-547-2010, 2010.

Marcato, G., Pasuto, A., and Rivelli, F. R.: Mass movements in the Rio Grande Valley (Quebrada de Humahuaca, Northwestern Argentina): a methodological approach to reduce the risk, Adv. Geosci., 22, 59-65, doi:10.5194/adgeo-22-59-2009, 2009.
Mon, R. and Salfity, J. A.: Tectonic evolution of the Andes of Northern Argentina, in: Petroleum basins of South America, edited by: Tankard, A. J., Suarez, R. S., and Welsink, H. J., American Association of petroleum Geologist Memoir, 62, 269-283, 1995.

Moreiras, S. M.: Climatic effect of ENSO associated with landslide occurrence in the Central Andes, Mendoza Province, Argentina, Landslides, 2, 53-59, 2005.

National Research Council: Committee on Alluvial Fan Flooding, Water Science and Technology Board, Commission on Geosciences, Environment, and Resources, Alluvial fan flooding, National Academy Press, Washington, DC, 1996.

Ramos, V. A., Turic, M. A., and Zuzek, A. B.: Geologia de las Quebradas de Huichara-Pocoya, Purmamarca y Tumbaya Grande en la Margen Derecha de la Quebrada de Humahuaca (provincia de Jujuy), Rvista de la Asociacion Geologica Argentina, 22, 209221, 1967.

Repiso, L. I., Ravegnini, N., and Sleive, E. P.: Sustainable design in heritage sites: An archeological park in Argentina, Open House Int., 32, 83-97, 2007.

Robinson, R. A. J., Spencer, J. Q. G., Strecker, M. R., Richter, A., and Alonso, R. N.: Luminescence dating of alluvial fans in intramontane basins of NW Argentina, Geological Society, London, Special Publications, 251, 153-168, 2005.

Salfity, J. A., Brandán, E. M., Monaldi, C. R., and Gallardo, E. F.: Tectónica compresiva cuaternaria en la Cordillera Oriental Argentina, Latitud de Tilcara (Jujuy), IX Congreso Geológico Argentino, Actas II, 427-434, 1984.

Sancho, C., Pena, J. L., Rivelli, F., Rhodes, E., and Munoz, A.: Geomorphological evolution of the Tilcara alluvial fan (Jujuy Province, NW Argentina): Tectonic implications and palaeoenvironmental considerations, J. S. Am. Earth Sci., 26, 68-77, 2008.

Schick, A. P., Grodek, T., and Wolman, M. G.: Hydrologic process and geomorphic constraints on urbanization of alluvial fan slopes, Geomorphology, 31, 325-335, 1999.

Trauth, M. H., Bookhagen, B., Marwan, N., and Strecker M. R.: Multiple landslide clusters record Quaternary climate changes in the northwestern Argentine Andes. Palaeogeogr. Palaeocl., 194, 109-121, 2003.

Turner, J. C. M.: The Andes of Northwestern Argentina, Geol. Rundsch., 59, 1028-1063, 1970.

UNESCO: The list of the World heritage sites, available at: http: //whc.unesco.org/en/list/1116, 2003. 